\title{
PLATO, NUMENIUS AND CLEMENT OF ALEXANDRIA ON THE DIVINE STEERSMAN*
}

\begin{abstract}
Summary: The paper aims to show that the suggestion of Alain Le Boulluec, delivered in his commentary, according to which Clement's divine steersman, in Stromateis VII 5, may be a criticism of Numenius, is right. Clement is alluding to the Platonic myth in the Statesman while opposing some elements of this view. There are common moments between Numenius' and Clement's interpretations which are not present in Plato's account. Clement shares only the positive aspect of the activity of the Son of God described by Numenius. He rejects the Numenian dualistic ontology and its consequence, the movement, the division and the split of the second divine figure providing the sequences of providential and non-providential conditions of the world.
\end{abstract}

Key words: Greek patristics, Platonic cosmology, Middle Platonism, providence, Second God, Alexandrian tradition

\section{THE SON OF GOD IN THE STROMATEIS OF CLEMENT OF ALEXANDRIA AND THE DIVINE STEERSMAN OF PLATO'S MYTH}

The seventh book of Clement of Alexandria's Stromateis offers one of the most concise accounts of the providential activity of the Son of God:

Thus the most excellent thing on earth is the most devout of men, and the most excellent in heaven is the angel, who is nearer in place to the deity and already more purely participates in the eternal and blessed life. But most perfect and most holy of all, most sovereign, most lordly, most royal, and most beneficent, is the nature of the Son, which approaches

\footnotetext{
${ }^{*}$ The research has been supported by the Hungarian Research Fund (OTKA project K 81278). I thank Mark Randall James for correcting my English text, and I thank George Boys-Stones for the permission of quoting his unpublished translation of Numenius' fragments.
} 
most closely to the One Almighty Being. The nature of the Son is the highest pre-eminence, which sets in order all things according to the Father's will, and steers the universe aright, performing all things with unwearying energy, beholding the Father's secret thoughts through his working. For the Son of God never moves from his observation-point, being never divided, never dissevered, never passing from place to place, but existing everywhere at all times and free from all limitations. He is all reason, all eye, all light from the Father, seeing all things, hearing all things, knowing all things, with power searching the powers. To him is subjected the whole army of angels and of gods - to him, the Word of the Father, who has received the holy administration by reason of him who subjected it to him; through whom also all men belong to him, but some by way of knowledge, while others have not yet attained to this; some as friends, some as faithful servants, others as servants merely. ${ }^{1}$

This passage is informative in several different respects. It contains Presocratic ma-

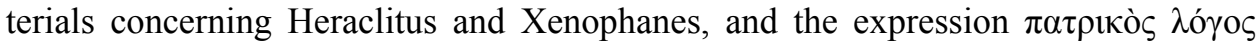
may provide a key to the interpretation of the fragment of the Hypotyposes quoted critically by Photius. ${ }^{2}$ The seventh book of the Stromateis, including these lines, has also been the object of several recent investigations, ${ }^{3}$ but I would like to limit myself to proving the suggestion of Alain Le Boulluec, delivered in his commentary, that Clement's divine steersman, inspired by Plato and Numenius, may offer a criticism of Numenius. ${ }^{4}$ Thus, I do not deal with the very obscure Platonic myth in the Statesman,

${ }^{1} \tau \alpha \cup ́ \tau \eta \eta$

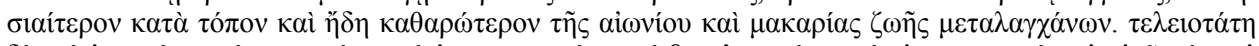

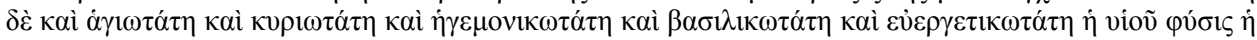

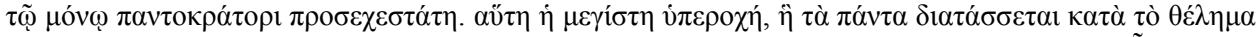

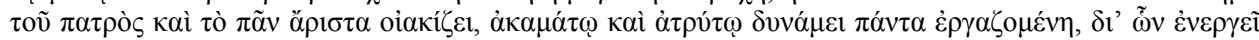

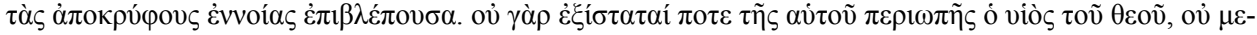

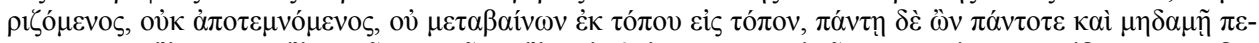

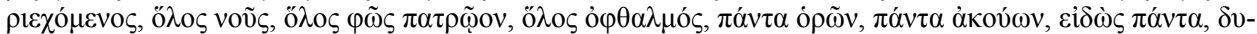

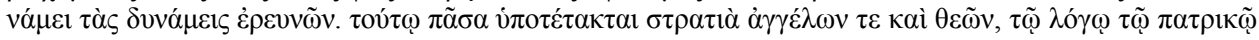

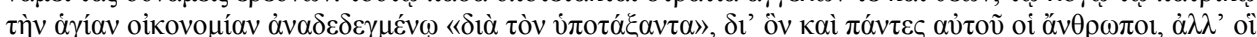

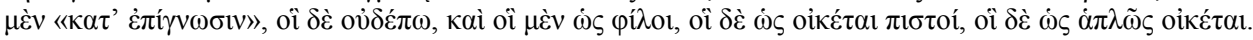
Str. VII (II) 5. Cf. Clement d'Alexandrie, Stromate VII. Ed. A. LE BoulluEC. Sources Chrétiennes [SC] 428, 48. 4 - 50. 25. Slightly modified translation by CHADWICK, H. - Oulton, J. E. L. (eds.): Alexandrian Christianity. Selected translations of Clement and Origen. Louisville 1954 (reissued 2006), 95-96.

${ }^{2}$ CASEY, R. P.: Clement and the two divine logoi. JThS 25 (1989) 43-56. M. J. EDWARDS' analysis gives a better solution: Clement of Alexandria and His Doctrine of the Logos. VChr 54 (2000) 159-177. For a thorough recent study on this question, see GYURKOVICS, M.: Il duplice Logos divino e umano - La teologia del Logos da Clemente di Alessandria a Fozio di Costatinapoli. Eastern Theological Journal 1.1 (2015) 99-133.

${ }^{3}$ The Seventh Book of the Stromateis. Eds. M. HAVRDA - V. HuŠEK - J. PlÁtOVÁ. Leiden-Boston 2012, see especially the summary and the bibliography of the recent scholarship on the Seventh Book offered by A. VAN DEN HOEK, 3-36.

${ }^{4}$ A. Le BoullueC in $S C 428,49$, n. 7: “Clément s'oppose peut-être à la pensée de Numenius sur « le deuxième et troisième Dieu »..." The parallel between steersman and ship on the one side and providential God and cosmos on the other occur in some other texts. The author of the De mundo uses the

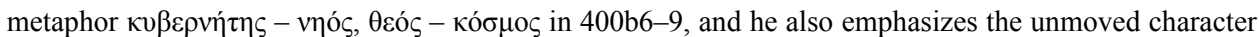


where the philosopher tries to explain the periods of the golden age, the present time, and the cataclysms dividing these ages by the rhythmical passivity and activity of the divine pilot.

The most characteristic common element of the Platonic and Clementian accounts is the word $\pi \varepsilon \rho 1 \omega \pi \eta$, which is a hapax legomenon in Plato's texts. It signifies a "place commanding a wide view", a "place of vantage", an "observation-point",

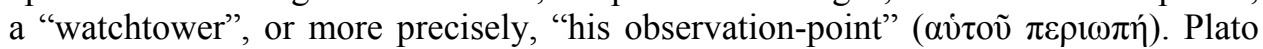
says as follows:

When the time of all these things had been completed and the hour for change had come, and in particular all the earth-born race had been used up, each soul having rendered its sum of births, falling to the earth as seed as many times as had been laid down for each, at that point the steersman of the universe, let go - as it were - of the bar of the steering-oars and retired to his observation-point; and as for the cosmos, its allotted and innate desire turned it back again in the opposite direction. ${ }^{5}$

While in Plato's account the steersman is leaving the bar of the steering-oars and retires to his observation-point, in Clement's description the main issue is that the Son of God does not move from his observation-point. This means that Plato's and Clement's observation-points are not the same place. It is a very difficult question where the observation-point in Plato's myth can be found. It would be logical if this vantage point commanding a wide view were situated on the ship, because no steersman could have been able to walk across the surface of the open sea to an observationpoint lying outside of the ship, but the myth is not necessary logical. Antique ship illustrations only rarely posit an observation-point above the place of the pilot. In most cases, the highest point corresponds to the seat of the steersman. Sometimes, in the case of warships, a watcher stays in the rostrum, but his position is not situated higher than that of the steersman. Some frescos of Akrotiri from the Mycenaean time posit a cabin as a higher observation-point behind the steersman, providing a wide panoramic view. ${ }^{6}$ But this fact cannot prove that in Plato's text the ship is the residence of the God when he leaves the bar of the steering-oars. In the mythical account of the Statesman the two distinct metaphors of the ship with the pilot on the hand side and the figure of the God who rotates the universe on the other, imperceptibly interlace. Thus, there is no impossibility in the displacement of the God.

of the God. Although Clement of Alexandria knew this treatise (see Bos, A. P.: Clement of Alexandria on Aristotle's (Cosmo-)Theology. CQ 43 [1993] 177-188), I do not think that our text depends on this passage of De mundo. Inter alia the same metaphor can be found in Maximus of Tyr IV $9 \mathrm{~d} 2-3$, where the author criticizes the Epicurean view of theology. But these two texts do not use the word $\pi \varepsilon \rho 1 \omega \pi \eta$.

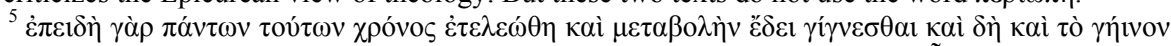

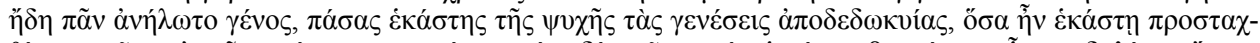

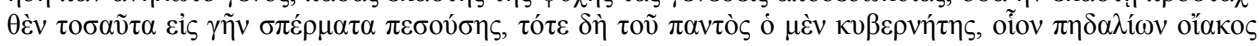

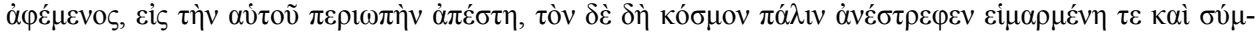

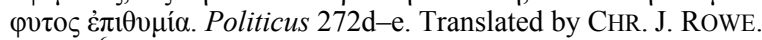

${ }^{6}$ TARTARON, T. F.: Maritime Networks in the Mycenaean World. Cambridge 2013, 56. 
Despite the differences in the steersman's positions in Plato's and Clement's accounts, there is no question that the mythic framework is identical. Both texts offer a description of divine providence. The Heraclitean ${ }^{7}$ word oi $\alpha \kappa i \zeta \varepsilon 1$, adapted by Clement, obviously refers to the navigation of the ship, while the principal meaning of the word ol $\alpha \xi$ used in Plato's myth in the Statesman is 'handle of rudder'. When Clement

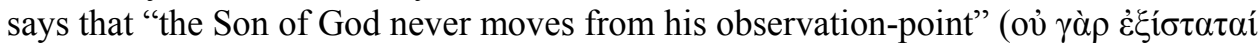

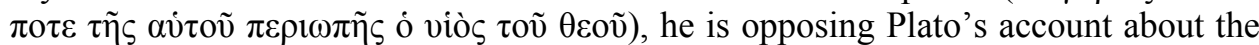

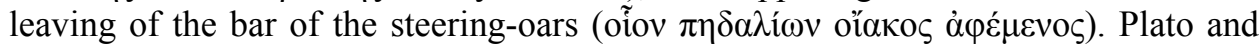
Clement do not use the same word for leaving the place, but both use verbs derived from i $\sigma \tau \eta$ t. Furthermore, they similarly refer to the gods and angels as instruments of providence. Thus, it is obvious that Clement is alluding to the Platonic myth delivered in the Statesman while opposing some elements of this view. Clement's position is clear: the Son of God never interrupts the governing of the universe, and the situation described by Plato in this way, “... as for the cosmos, its allotted and innate desire

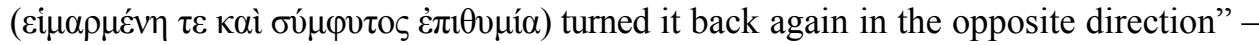
never occurs. Plato tries to explain the cataclysms of the cosmos using astronomical ideas within the frame of a cyclic world-view, but for Clement this is not a real question. He does not deal with problems of natural philosophy and astronomy, and he does not share the cyclic view of history or the philosophical concept of matter as something independent from God. According to Clement, the divine Logos never leaves the bar of the steering-oars and his observation-point. Obviously, Clement uses the Platonic myth freely, because the positions of the Platonic bar of the steering-oars and the observation-point become one point in his interpretation. ${ }^{8}$

\section{THE INTERPRETATIONS OF CLEMENT OF ALEXANDRIA AND NUMENIUS OF APAMEA}

Here another question arises, namely, whether there is any other philosopher using the Platonic motif of the divine ruler. I think that there is. In Clement's text the immobility of the Son of God is strongly emphasized: "For the Son of God never moves from his observation-point, being never divided, never dissevered, never passing from place to place, but existing everywhere at all times and free from all limitations." While Plato attributes minimal or roughly circumscribed movement to the steersman, Numenius of Apamea, the middle Platonist-Neopythagorean philosopher, who lived in the second century AD, offers an interpretation of Plato's myth in which the motion of the divine steersman plays an idiosyncratic role. In contrast to the middle Platonic philosophers, and similarly to Neoplatonic ones, Numenius is trying to explain the function of the divine ruler in the fragments of his book On the Good through an interpretation of the Statesman.

\footnotetext{
${ }^{7}$ Heraclitus frg. 64 D-K.

${ }^{8}$ Clement mentions the $\pi \varepsilon \rho \iota \omega \pi \eta$ in Protrepticus 6. 68. 3, and here the observation-point belongs to the Unbegotten God.
}

Acta Ant. Hung. 56, 2016 
Numenius is the most famous philosopher in the Platonic and Pythagorean traditions during the second half of the second century. We possess only fragments from him, and most of them have come down to us via Eusebius and Proclus. ${ }^{9}$ Due to his style, Numenius seemed a bit baffling even to his immediate posterity. Porphyry mentions in his Vita Plotini that "... the people from Greece began to say that Plotinus was appropriating the ideas of Numenius...", and then quotes Amelius protesting this charge of plagiarism. Amelius contends: "You must treat it with justified indulgence ... and besides, the intention of our friend (sc. Numenius), who is being put on trial for the opinions which he shares with us, is not very easy to grasp, because he treats the same subjects in different ways in different places." ${ }^{10}$ Longinus blames Numenius for his lack of accuracy $(\dot{\alpha} \kappa \rho i \beta \varepsilon 1 \alpha)$, contrasting him with Plotinus in this respect, and Proclus also criticizes him for using "dramatic language". ${ }^{11}$ The fragmentary character of Numenius' writings makes them even more difficult for us to understand. Consequently, they need thorough interpretation. ${ }^{12}$ Due to his attitude towards Pythagoras and the secret myths, the lucidity of the old texts was not a criterion of their excellence for Numenius, which makes it still more difficult to understand his fragments. The Apamean philosopher justified the veiled way of speaking in philosophy and mythical traditions with practical considerations.

Some scholars have been inclined to regard Numenius as the trail-blazer of Oriental anti-intellectualistic spiritual trends - for instance, of gnosis - or as a Jewish author. ${ }^{13}$ Others look upon him as a follower of the Hellenistic rationalist tradition, who, like many other philosophers, showed partial interest in Oriental, barbaric wisdom. ${ }^{14}$ It is evident that Numenius accepted pieces of the teaching of "peoples of renown" which seemed to harmonize with the doctrines of Pythagoras, Socrates and Plato, that is, with his own interpretation of Platonic texts. Among the "peoples of renown" Numenius mentions the Egyptians, the Brahmans, the Magi, and the Jews. ${ }^{15}$

\footnotetext{
${ }^{9}$ Quite a number of fragments have survived from two of his writings: On the Good was written in a dialogue-form, the other bears the title On the Dissension between the Academy and Plato.

${ }^{10}$ Vita Plotini 17. 1-2 and 31-39, translated by A. H. ARMSTRONG.

${ }^{11}(\lambda \varepsilon \dot{\gamma \varepsilon 1} \pi \rho 0 \sigma \tau \rho \alpha \gamma \omega \delta \tilde{\varphi} v)$ Proclus, Commentary on Timaios I 303. 27 - 304.7, frg. 21.

${ }^{12}$ One of the essential features of the Numenian texts is the close connection between old religion and philosophy on the basis of allegorical interpretation.

${ }^{13}$ BIGG, CH.: The Christian Platonist of Alexandria. Oxford 1923, 300; PUECH, H.CH.: Numénius d'Apamée et les théologies orientales au second siècle. AIPhO 2 (1934) 745-778.

${ }^{14}$ BeUTLER, R.: Numenius. In PWRE Suppl. 7 (1940) and A.-J. FESTUGIÈRE in volumes III and IV of La révélation d'Hermès Trismégiste. Paris 1953-1954. This latter trend is the stronger in modern Numenius research; at least H. J. Kraemer, E. R. Dodds, J. Dillon, M. Frede, J. H. Waszink agree with this view. It is, of course, obvious that oriental influence should not be neglected, for example in Numenius' psychology. See MORESCHINI, C.: La posizione di Apuleio e della scuola di Gaio nell'ambito del medioplatonismo. ASNP 33 (1964) 17-56, esp. the third chapter on Middle-Platonic theology. NuFFELEN, P. VAN: Rethinking the Gods: Philosophical Reading of Religion in the Post-Hellenistic Period. Cambridge University Press 2011, 80 .

15 "On this matter, when one has set out a position and drawn one's conclusions, it will be necessary to retire into the testimony of Plato and bind it all together by the words of Pythagoras; and to call on the aid of those nations held in honour, as Plato did, adducing their rites and ordinances and their rituals of consecration - whatever Brahmans and Jews and Magi and Egyptians have organized." Frg. 1a, Eusebius, Praeparatio evangelica IX 7.1, 411b-c.
} 
Similarly, he was particularly interested in mystery cults (Mithratic mysteries, Eleusis). Although some philosophers' references to the Jewish tradition are not at all exceptional issues, Numenius also interpreted some episodes of the Jesus story, which suggests a closer affinity to the Jewish-Christian tradition. Origen writes the following: "In $\mathrm{On}$ the Good book 3, he even sets out a story about Jesus (though he doesn't mention the name), and gives it an allegorical interpretation." ${ }^{, 16}$ This fact presupposes a particular interest in Christianity, and it seems that Numenius is the first philosopher who does not disdain Christians. Thus, while he was a precursor of Plotinus and a major source for Porphyry, at the same time he was an important author for Christians, such as Clement of Alexandria, Origen and Eusebius. ${ }^{17}$

It should be highlighted that Clement of Alexandria is the first author who gives information on Numenius, and with the aid of his account the Apamean philosopher's activity can be dated. The terminus ante quem can be established by the reference to Numenius in the first book of the Stromateis, which was written around 197.

The following Clementian idea gained ground rapidly:

$\ldots$ so that it is perfectly clear that the above-mentioned philosopher [Plato] derived a great deal from this source, for he was very learned, as also Pythagoras, who transferred many things from our books to his own system of doctrines. And Numenius, the Pythagorean philosopher, expressly writes: 'For what is Plato, but Moses speaking in Attic Greek?' This Moses was a theologian and prophet, and as some say, an interpreter of sacred laws. ${ }^{18}$

Another version of this passage has been included in the collection of the Numenian fragments, as fragment 8, because in Eusebius' Praeparatio evangelica the source of this quotation can be identified as Numenius' On the Good. ${ }^{19}$ The Clementian quotation in itself does not imply that Clement had read the work of Apamean philosopher. Henry-Charles Puech, one of the first historians of Greek philosophy who attached great importance to Numenius' ideas, did not mention Clement of Alexandria among the Christian writers possessing Numenius' work in their libraries. ${ }^{20}$ It is possible that the Christian author heard or read somewhere the famous utterance that Plato is Moses speaking in Attic Greek. There are no other Clementian passages referring to Numenius. ${ }^{21}$ But it is difficult to think that such a Christian writer as Clement, who

${ }^{16}$ Frg. 10a, Contra Celsum IV 51.

${ }_{17}^{17}$ VAN NUFFELEN (n. 14) 72.

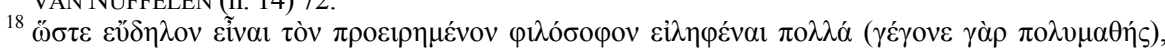

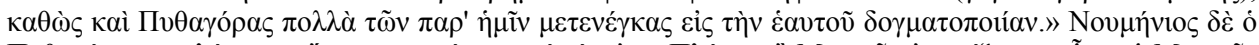

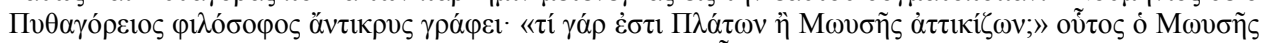

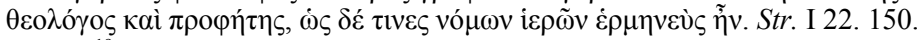

${ }_{19}$ Praeparatio evangelica XI 10. 12-14, 526d-527a. Theodor of Cyrus also cites this bon mot: Therap. II 114. 169.

${ }^{20}$ PUECH (n. 13).

${ }^{21}$ It is possible that the two-soul theory of Basilides and his son, Isidorus, which is taken by Clement of Alexandria as a Pythagorean doctrine, derives from Numenius' works (Str. II 20. 112.1 - 114. 3; cf. GCS 174).

Acta Ant. Hung. 56, 2016 
had tried to connect faith and knowledge, and who applied philosophical methods to deepen Christian doctrines, did not know and read the works of a Greek philosopher who sympathized with the Jewish and Christian tradition. ${ }^{22}$ This Pythagorean-Platonic line of Greek philosophical tradition was the most important school for Clement, who was one of the most erudite Patristic authors. Furthermore, at this time Clement was living in Alexandria, where he could get any book, and where Numenius was a popular author, whose books were read and commented in the school of Ammonius and Plotinus. Thus, it is almost certain that Clement of Alexandria knew Numenius' works.

The Numenian fragment 12 refers to the steersman of Plato's Stateman in the following way:

... the first God is not employed in any work at all, and is king. The creator God passes through the heavens and governs. Our equipment comes through him, since intellect is sent down for all those marshalled to join the expedition. When God looks at each of us, when he turns to us, then are our bodies alive and quickened, united with the radiance of God. When God turns back to his observation-point, our bodies are extinguished, though the intellect lives, enjoying a happy life. ${ }^{23}$

Here, I diverged from Boys-Stones' translation who renders the formula, $\mu \varepsilon \tau \alpha \sigma \tau \rho \varepsilon \varepsilon^{-}$

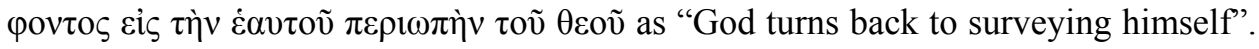
This might also be a correct translation. Before him Karl Mras also renders $\pi \varepsilon \rho 1 \omega \pi \eta ́$ as "Betrachtung" in his edition of Eusebius and argues that this is a pun on the words

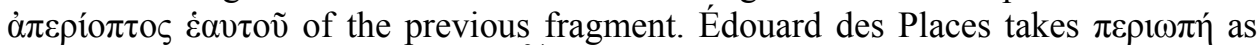
observation-point ("observatoire"). ${ }^{24}$ It is possible that in fragment 12 Numenius

${ }^{22}$ WASZINK, J. H.: Some Observations on the Appreciation of 'The Philosophy of the Barbarians' in Early Christian Literature. In ENGELS, L. J.et al. (ed.): Mélanges offerts à Mlle. Christine Mohrmann. Utrecht 1963, 55.

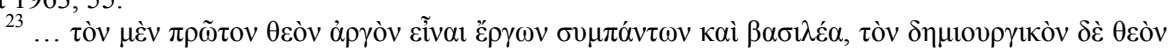

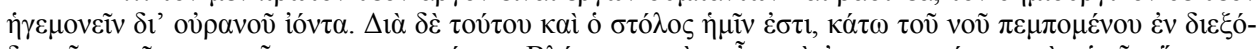

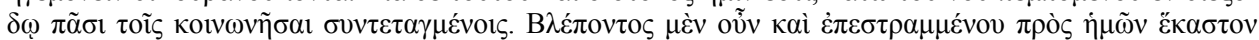

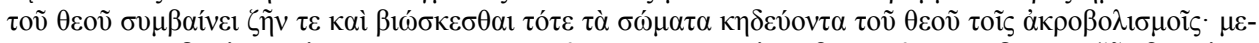

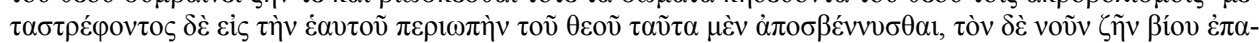

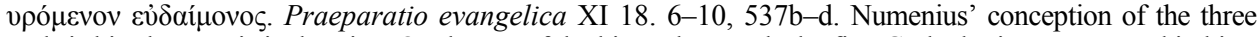
gods is his characteristic doctrine. On the top of the hierarchy stands the first God who is concentrated in himself, simple, indivisible, who does not take part in the creation of Cosmos, who is Goodness itself, the first

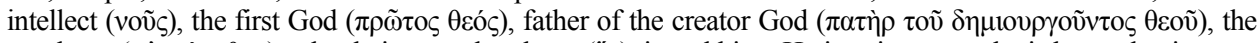

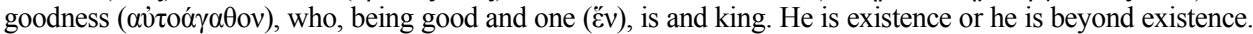
Although the first God is unmoved, his immobility is a sort of inner motion which sustains the order and the eternal continuance of the cosmos. The second God is identical with the Platonic demiurge, and he is also an intellect (voũs), though besides intellect he has other mental faculties, as well. Participating in the first Goodness he is good himself, too. In contrast with the first God, the second God is mobile; he keeps imitating the first God and he is intelligible. The third God is called $\pi$ oí $\mu \alpha$, work by Numenius, for he is probably the cosmos as Proclus proves in his Commentary on Timaios (I 303. 27 - 304. 7, frg. 21), and Origen is most likely referring to Numenius when he contends in Contra Celsum V 7 that certain philosophers regard the world as a third God.

${ }^{24}$ See n. 10 to frg. 12 in Numénius: Fragments. Ed. É. DES PLACES. Paris, Les Belles Lettres 1973, 108. 
alludes to the activity of the second God described in fragment 11, but this does not exclude the reference to the Platonic myth of the divine steersman which is explicit in fragments 11 and 18.

According to fragment 12, the demiurge passes through the heavens. I think that this motion would not have produced Clement's reaction. But in fragment $11 \mathrm{Nu}-$ menius raises the idea of the second God's imperfection, and he refers to the cause of this imperfection as the alienation from the initial position:

The first God, being in his own place, is simple; and being together with himself throughout, can never be divided. The second and third God, however, are one. He comes into contact with matter, but it is dyadic and, although he unifies it, he is divided by it, since it has an appetitive and fluid character. Because he is gazing on matter, he is not intent on the intelligible (for in that case he would have been intent on himself); and by giving his attention to matter he becomes heedless of himself. And he gets to grips with the perceptible and is absorbed in his work with it, and by devoting himself to matter he takes it up even into his own character. ${ }^{25}$

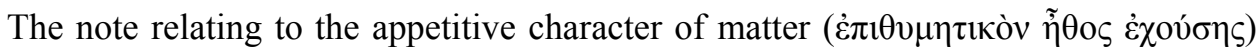
refers to the accounts of the Statesman 272e5-6, that "as for the cosmos, its allotted and innate desire turned it back again in the opposite direction" ( $\tau$ òv $\delta \dot{\varepsilon} \delta \grave{\eta े ~ \kappa o ́ \sigma \mu o v ~}$

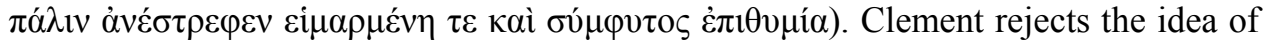
a split in the Son of God and his motion. Numenius' solution is akin to several Gnostic views about the imperfect character of the Creator. It is well known that Numenius intensified Platonic dualism. He pushed up the cosmic efficacy of evil to the sphere of heaven through his view on the difficult symbiosis of the God and matter, principle of the evil. Thus, matter also produces a split in the Creator ( $\left.\sigma \chi \chi_{i \zeta \varepsilon \tau \alpha l} \delta \dot{\varepsilon} v \dot{v} \pi^{\prime} \alpha \dot{v} \tau \tilde{\eta} \varsigma\right)$, when he is pursuing his providential activity on the material world, depicted for the most part as a sea or river. ${ }^{26}$ Naturally, this providential activity also has other characteristics. Numenius does not only emphasize the fact of the war between good and evil and the contamination of the creator caused by this contact with the bad soul, but also his divine and perfect character and this is connected to a more idyllic description

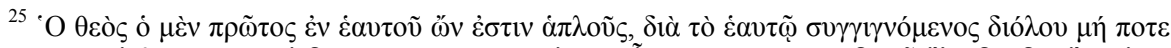

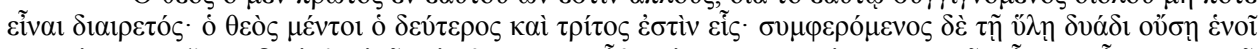

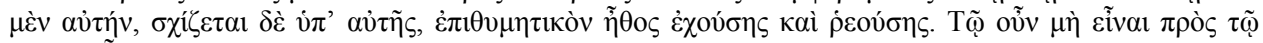

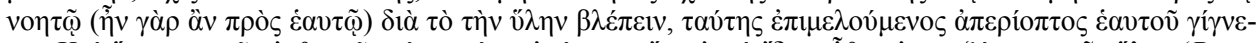

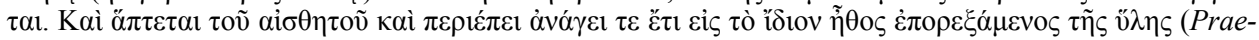
paratio evangelica XI 17. $11-18.5,536 \mathrm{~d}-537 \mathrm{~b}$ ). Thus, the third God, the cosmos is in a way "one with the second God". How can the demiurge be one with the Cosmos? How can the Cosmos possess the faculty of discursive thinking ( $\left.\delta t^{\prime} v o t \alpha\right)$, the only attribute the $\pi$ oí $\mu \alpha$-third God has according to Numenius' fragments? It seems to be the most acceptable explanation that the third God is the unity of cosmic order and the WorldSoul, and the World-Soul is one with the Demiurge in a certain respect (but not in the sense of identity), i.e. the World-Soul has an essential kinship with the Demiurge.

${ }^{26}$ Earlier, in my paper (SOMOS, R.: Numéniosz az anyagról [Numenius on Matter]. Passim 6.1 [2004] 137-147) I tried to show that the peculiarity of Numenius' theory of $\tilde{v} \lambda \eta$ is that matter is described as a fluid.

Acta Ant. Hung. 56, 2016 
of the universe ruled by the God. So, the steersman of the world puts on a solemn face in fragment 18 :

A steersman borne along in the middle of the sea sits high up, above the rudders, and steers the ship by their handles, but his eyes and mind are intent on the sky as he looks towards the heavens, so that as far as he is concerned his route follows a path through the heaven above, though he is sailing along the sea below. Just so the Creator, having bound matter together in a harmony that it cannot knock or slip away from, is himself seated above it, as above a ship on the sea. And he directs the harmony, steering by the forms; and instead of the heavens, he looks to the God above who draws his eyes to him; and he takes his faculty of judgement from that contemplation, and his faculty of impulse from his yearning. ${ }^{27}$

The starting point of rule by the faculty of judgement is that the providential God is looking to the First God, who is the First Intellect ( $\pi \rho \tilde{\omega} \tau \tau_{\varsigma} \varsigma$ voũs). This second God's principal activity is $\theta \varepsilon \omega \rho i \alpha$. We find a similar idea in Clement's description. The Son of God regards the secret thoughts ( the thoughts of the Father.

There are several other common moments between Numenius and Clement which are not present in Plato's account. The first issue is the presence of two divine persons. The presentation of the father-son relation between the two divine figures possessing the character of voũ s is important both for Numenius and Clement. The second point is that during the ruling of the world, the second divine person is pursuing his providential activity by contemplating the thoughts of the first divine figure. But Clement shares only the positive, idyllic aspect of the activity of the Son of God. He rejects the Numenian dualistic ontology and its consequence, the movement, the division and the split of the second divine figure providing the sequences of providential and non-providential conditions of the world. Clement of Alexandria emphasizes the fact that "the Son of God never moves from his observation-point, being never divided, never dissevered, never passing from place to place, but existing everywhere

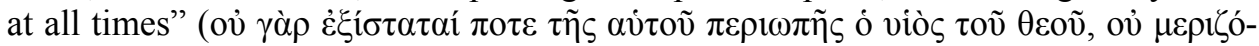

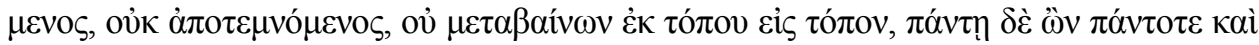
$\left.\mu \eta \delta \alpha \mu \tilde{\eta} \pi \varepsilon \rho \iota \varepsilon \chi{ }^{\prime} \mu \varepsilon v o \varsigma\right)$. It is also possible that the quoted fragment 18 of Numenius may provide an answer to the oddity, why the seat of the steersman coincides with the observation-point in Clement's account. In this passage, Numenius positions the seat of the steersman so high that it can be seen as an observation-point providing a large panorama, like a $\pi \varepsilon \rho \omega \pi \eta$. Furthermore, when speaking about the providential and non-

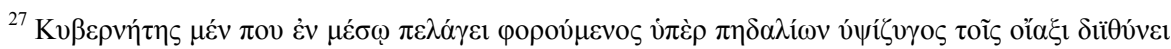

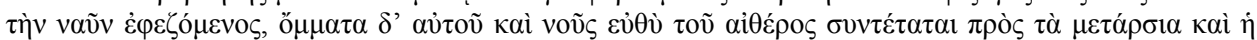

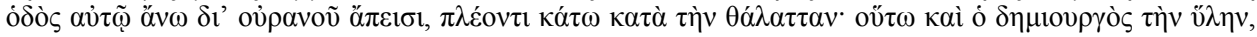

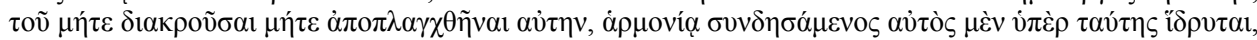

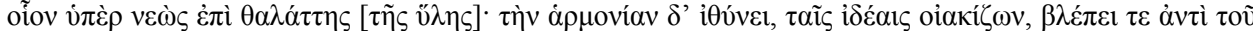

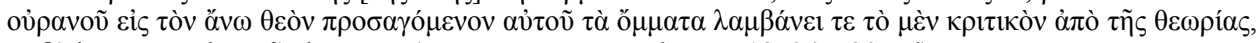

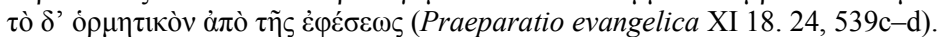


providential cycles of the world process, Numenius does not attribute spatial motion to them but rather turning in this or that direction, which is not alien to the two different lines of the Platonic Statesman's myth, the metaphors of the seaman and the turn of the world in different directions made by the God. This reconstructed characteristic meaning of the Numenian fragments may explain the fact that Clement of Alexandria did not distinguish the position of the steersman, who rules the world in an uninterrupted way, and that of the observation-point of the Son of God.

\author{
Róbert Somos \\ Department of Philosophy \\ University of Pécs \\ Ifjúság útja $6 / b$ \\ H-7624 Pécs \\ Hungary
}

